Article

\title{
Long-Term Orientation as a Resource for Entrepreneurial Orientation in Private Family Firms: The Need for Participative Decision Making
}

\author{
Jelle Schepers ${ }^{1, *(\mathbb{D}, \text { Wim Voordeckers }}{ }^{1}\left(\mathbb{D}\right.$, Tensie Steijvers ${ }^{1}\left(\mathbb{D}\right.$ and Eddy Laveren ${ }^{2}(\mathbb{D}$ \\ 1 Research Center for Entrepreneurship and Family Firms (RCEF), Hasselt University, Agoralaan, Building D, \\ 3590 Diepenbeek, Belgium; wim.voordeckers@uhasselt.be (W.V.); tensie.steijvers@uhasselt.be (T.S.) \\ 2 Department of Accountancy and Finance, University of Antwerp, Prinsstraat 13, 2000 Antwerpen, Belgium; \\ eddy.laveren@uantwerpen.be \\ * Correspondence: jelle.schepers@uhasselt.be
}

Received: 5 June 2020; Accepted: 29 June 2020; Published: 1 July 2020

\begin{abstract}
Building on the resource-based view (RBV) of the firm, this paper suggests that a family firm's long-term orientation (LTO) can be an important resource that increases firm-level entrepreneurial orientation (EO). Nevertheless, resource orchestration suggests that managers need to orchestrate their resources in order to realize any potential advantage. Therefore, we hypothesize that a family firm's LTO entails potential resources to engage in entrepreneurial activities, while a participative decision making (PDM) style serves as coordinating mechanism that helps the firm to manage these resources. Using data from 209 private family firms, the results show a positive association between LTO and EO. Also, PDM was found to positively moderate the LTO-EO relationship, providing empirical support for our central hypothesis.
\end{abstract}

Keywords: Long-term orientation; entrepreneurial orientation; participative decision making; private family firms

\section{Introduction}

Over the years, entrepreneurial orientation (EO) has emerged as a key construct within the strategic management and entrepreneurship literatures. The concept of EO dates back to Miller's [1] seminal paper, in which entrepreneurial firms are described as "those that are geared towards innovation in the product-market field by carrying out risky initiatives, and which are the first to develop innovations in a proactive way in an attempt to defeat their competitors" (p. 771). Since EO is found to be a critical driver for firm growth, profitability and sustainability of family firms, researchers are gaining interest in potential drivers of $\mathrm{EO}$.

In a family business context, several distinctive characteristics that may hamper or foster entrepreneurship, like for example generational involvement and organizational culture, were revealed e.g., [2-5]. Especially, the extent to which a family business' long-term orientation (LTO), defined as the tendency to prioritize the long-range implications and impact of decisions and actions that come to fruition after an extended time period [6-8], hinders or promotes entrepreneurship has been of particular interest. In general, family business scholars e.g., $[6,7,9,10]$ agree that family firms have a longer-term orientation relative to their non-family counterparts to safeguard the sustainability of their family business [11-13], but its relationship with EO remains unclear. In this context, Zahra et al. [3] investigated the effect of a family firm's time-orientation on their willingness to engage in entrepreneurial activities. They argue that longer planning horizons can generate a sustained competitive advantage [14] and create commitment towards long-term value creating activities such as entrepreneurship. Relying on the resource-based 
view (RBV) of the firm, Zahra et.al [3] find empirical support for a positive association between LTO and entrepreneurship in family firms [3]. Lumpkin et al. [6] on the other hand, propose that a family firm's LTO is positively associated with innovativeness and proactiveness, but at the same time LTO may reduce the firm's willingness to venture into the unknown. Although they did not empirically test their propositions, it is clear that the relationship between a family firm's LTO and their EO is equivocal and remains to be studied [9]. In sum, Lumpkin et al. [6] encourage future researchers to further explore the LTO-EO relationship in family firms by investigating how contingency variables, like the firm's management style, could intervene or moderate the relationship between LTO and EO.

Therefore, this article elaborates on participative decision making (PDM) in private family firms and its moderating role in the LTO-EO relationship. Namely, PDM refers to the degree to which the firm's main strategic and operating decisions are made through consensus seeking versus individualistic or autocratic processes by the formally responsible executive [15]. Although LTO must be seen as the dominant logic that is held by the family firm's dominant coalition e.g., $[9,10,16]$, there may be periods in which the firm has to face significant pressure on short-term results [17]. During these periods of increased short-term pressure, PDM can serve as a coordinating mechanism that ensures managerial commitment [18] towards their dominant logic (LTO) and prevents that relational conflicts will prevail [19]. Since it is known that relational conflicts may impede entrepreneurial behavior [19-21], PDM can be seen as a means that strengthens the LTO-EO relationship by reducing potential relational conflicts [19]. Building on Zahra et al.'s [3] findings, we suggest that a family firm's LTO can serve as a unique resource $[22,23]$ that adds to advanced levels of EO, but simply owning this resource is not enough; instead, family firms should orchestrate their resources in order to be more entrepreneurial.

Taken together, previous research has demonstrated that a family firm's time orientation affects their preference to engage in entrepreneurship (e.g., [3,6]) but the extent and direction of this relationship remains unclear [9]. More specifically, Lumpkin et al. [6] have called to investigate how different management styles intervene in the LTO-EO relationship. The present work is designed to fill this gap by introducing the idea that a family firm's decision-making style influences the link between their temporal orientation and entrepreneurship. This research provides a unique contribution to both family business and entrepreneurship literature by empirically investigating how the proposed relationship between a family firm's LTO and EO [6] alters under changed types of decision making (e.g., autocratic vs. participative). We propose that, PDM will serve as a mechanism that moderates the LTO-EO relationship so that LTO will have a more positive effect on EO when the level of PDM increases. Furthermore, this research also contributes to a similar discussion in strategic management literature by answering Lin et al.'s [24] recent call to investigate how top manager's decision-making styles influence the relationship between temporal orientation and strategic decision-making processes, like EO.

The remainder of this article is structured into five sections. First, we provide a theoretical framework where we define the key constructs (i.e., LTO, EO, and PDM) of our conceptual model (cf. Figure 1), situate them in the appropriate theoretical and empirical literature, and derive our hypotheses. Second, in the materials and method section we describe our sample and explain which variables and measures we used to test these hypotheses. Third, we elaborate our research method and present our results based on robust linear regression analysis and Brambor, Clark, and Golder's [25] marginal effect analysis. Next, we discuss our results, suggest some future research areas and provide some managerial recommendations. Finally, the paper ends with a brief conclusion. 


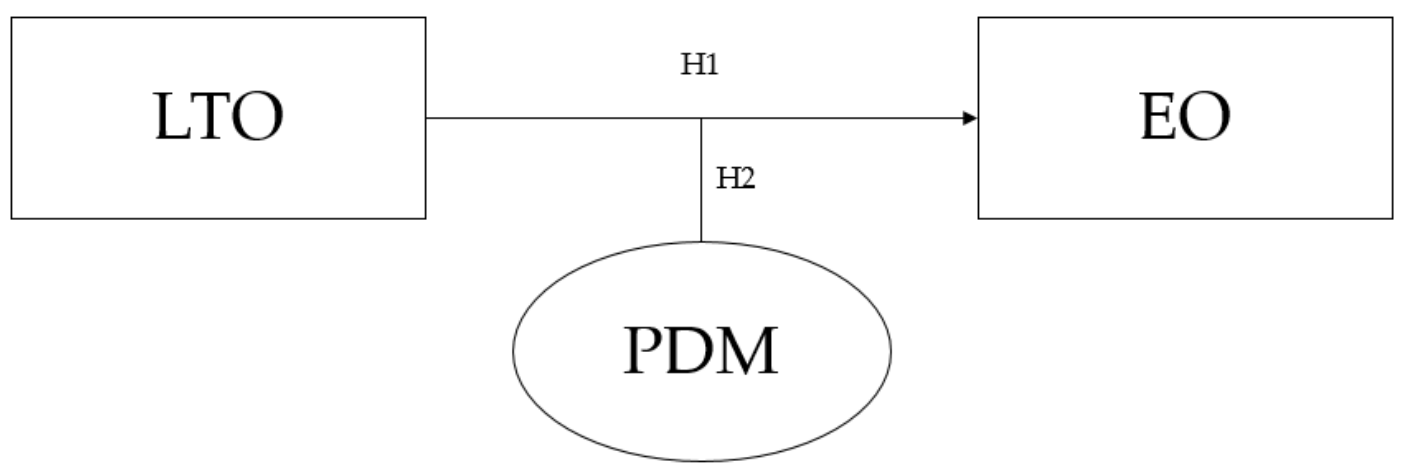

Figure 1. Research framework including long-term orientation (LTO), entrepreneurial orientation (EO) and participative decision-making (PDM).

\section{Theoretical Framework}

\subsection{Long-Term Orientation in Private Family Firms and Its Relationship with Entrepreneurial Orientation}

Compared to non-family firms, it seems that family firms tend to have greater interest in their long-run performance and they usually display a longer CEO tenure [26,27]. Furthermore, family firms usually try to transfer the firm to the upcoming generation $[28,29]$ and they generally have committed shareholders providing patient capital [30,31]. Family governance, especially through family ownership, can lead to strategic decisions and activities such as the adoption of sustainability practices which directly relate to the long-term continuity of the business e.g. [31-34]. Therefore, having an LTO is often labeled as a prevalent characteristic of many family firms. Indeed, a family firm's orientation towards time has been extensively studied by numerous scholars, using different labels, for example, "long-term nature of founding family ownership" [35], "longer planning horizons" [26,36], and a "long-time horizon" [28]. Furthermore, recent evolutions in family business literature have shown that family firm behavior can often be explained by their desire to maintain the continuity of the business across generations and their willingness to perpetuate the family dynasty $[28,36,37]$. In sum, given their particular orientation towards time, family firms provide us an interesting research context to investigate whether an LTO fosters or hinders these firms in pursuing entrepreneurial opportunities. To investigate this relationship, we use an EO framework, where EO is seen as the concurrent exhibition of innovativeness, risk-taking, and proactiveness which is in line with Miller [1] and Covin and Slevin's [38] conceptualization of EO.

In general, it seems that having an LTO is supportive for the level of EO in family firms $[3,6]$. The rationale behind this positive relationship can be found in the RBV of the firm. In particular, the RBV advocates that possessing valuable and rare resources provides the basis for value creation [23]. The RBV of the firm has been successfully used in different contexts to explain a firm's competitive advantage as a result of their internal attributes rather than external industry dynamics or economic conditions [39]. Namely, the RBV asserts that firms are heterogeneous and that it is the bundle of resources residing in the firm that gives them an opportunity to outcompete their competitors [14]. These so called "resources" can include both physical (e.g., a unique location or assembly line) and intangible assets (e.g., brand recognition, patents), individual (e.g. CEO's tacit knowledge) and corporate skills (e.g., marketing), organizational processes (e.g., communication flows), and the like [14]. Even more, looking at the original definition introduced by Wernerfelt [40], a "resource" is anything that can be considered as a strength of a firm [40,41]. 
In family business literature, the RBV has been used extensively to identify the nature and antecedents of their competitive advantage e.g., [39,41-44]. In this light, and while not necessarily unique to family firms, having an LTO has been identified as a resource prevalent among them e.g. [11,45-47]. Consequently, the RBV of the firm has been suggested as an appropriate theoretical framework to investigate LTO in a family business context. For example, Brigham et al. (2014) suggested to integrate LTO in the RBV of the firm to investigate if a long-term perspective could be a potential resource of competitive advantage for family firms. Generally, in family-owned firms, employees are permitted more latitude and discretion in investing in long-term projects including innovations with greater potential returns [46].

Moreover, recent evolutions in the RBV tend to move beyond a direct resource-performance relationship and try to capture how these resources, like LTO, can potentially result in performance gains e.g., [48,49]. In order to gain a better understanding of the relationship between a firm's resources and their effect on firm performance, researchers have identified other intervening variables through which a firm can gain a competitive advantage, like EO. Indeed, EO is seen as a resource consuming strategic orientation e.g. [38,50,51], meaning that access to more resources facilitates $\mathrm{EO}$ [50], which-in the end-can potentially result in a competitive advantage.

In 2004, Zahra et al. [3] used an RBV lens to introduce LTO as an important strategic resource that provides the firm a well-defined advantage over their rivals by endorsing and nourishing entrepreneurial activities. Namely, an organization's temporal orientation is reflected in its choice of control systems $[3,52,53]$ which can stimulate or hamper entrepreneurship. Indeed, organizations that have a short-term orientation tend to favor financial control systems, which are often based on hard performance quotas and established goals or targets. Financial controls are known to reduce employee's willingness to undertake the risks associated with entrepreneurship $[3,54]$. On the other hand, organizations that have a long-term orientation tend to favor strategic, rather than financial controls. The use of strategic controls requires a deep understanding of the work to be done, the associated risks, and alternative actions the firm might take. Strategic controls are more subjective in nature (e.g., customer satisfaction) and require face-to-face meetings with managers and employees to evaluate company performance, which stimulates entrepreneurial behavior in organizations [3]. Also, long-term oriented relationships with employees focused on social (e.g., face-to-face meetings to evaluate performance) rather than economic exchanges can boost employee commitment (e.g., [55-57]), which increases employee's entrepreneurial efforts beyond those formally required by the company $[55,56]$. Consequently, employees will show higher levels of entrepreneurship as they voluntarily pursue innovative ideas, gather information about latent or ongoing fluctuations in the market, or even evaluate competitors' moves [57].

Moreover, it seems that entrepreneurial efforts generally require years to pay-off and only come to fruition after an extended period of time e.g. [58-60], making it more likely that firms with an LTO will invest in EO. In line with this, recent studies e.g. [61,62] found that an LTO enables firms to focus on future returns and acknowledge the potential value of entrepreneurial efforts, such as R\&D investments. By definition, these entrepreneurial efforts are about the firm's future (e.g., new processes, advancements, breakthrough innovations) helping them to succeed under changing market conditions [59]. Thus, we propose the following hypothesis:

Hypothesis 1. There is a positive relationship between a family firm's long-term orientation and their entrepreneurial orientation. 


\subsection{Participative Decision Making as a Coordinating Mechanism}

Although LTO can serve as a resource for a family firm's EO, merely possessing such a resource does not always guarantee that the firm will in fact exhibit higher levels of EO. Indeed, the management of the firm needs to take actions to facilitate efforts that allow the firm to effectively exploit their resources. Namely, to realize value creation, firms/managers must transform or exploit the resources at hand $[22,23]$. Applied to our research question, LTO can be seen as a specific resource for family firms to engage in entrepreneurial activities but simply possessing this resource is insufficient. Surprisingly, past research on LTO and EO has implicitly assumed that the required actions to exploit these resources are unambiguous when they are not. This gap was already identified by Lumpkin [6] who invited future researchers to investigate how different management styles intervene in the LTO-EO relationship. Especially, the way in which family firms make decisions and deal with potential internal conflicts, could be an important contingency on the direct relationship between LTO and EO [6]. Therefore, the goal of this paper is to unravel how and when LTO is seen as a resource that increases a family firm's EO.

Basically, the main idea of resource orchestration, grounded in RBV theory, is that managers play an important role in the exploitation of firm resources [63]. In resource based theory, the role of mangers is often underdeveloped, especially in terms of processes and actions they initiate and oversee [64]. Thus, while the RBV has a very simple vision about how firm resources are connected to value creating activities, Sirmon et al.'s [63] idea of resource orchestration posits that what an organization does with its resources is equally important as which resources it possesses. Stated differently, owning valuable resources alone does not automatically secure the development of competitive advantage through entrepreneurship. An emerging stream of empirical papers supports the idea of resource orchestration as a means of managing a firm's resources to achieve maximum value from them, e.g. $[65,66]$. Accordingly, orchestrating resources, like a family firm's LTO, is critical for accurate implementation $[22,63,67]$. Similarly, when the collective mind-set of a family firm's dominant coalition is focused on the long-run (LTO), they possess an essential resource to engage in entrepreneurial activities (EO) because these entrepreneurial actions only come to fruition after an extended time period [58]. Nevertheless, in line with the idea of resource orchestration, managers must orchestrate the resources at hand (LTO) in order to result in entrepreneurial efforts (EO).

Family firms with an LTO are often provided with patient capital [11] which makes them more willing to focus on opportunities that generate wealth for future generations [26]. The consequence of this LTO is that it facilitates family firms to seek investment opportunities that non-family firms with short-term horizons do not consider important $[26,68]$. Nevertheless, along the way family firms can face significant short-term pressures that require immediate measures for improvement of short-term results [17]. During these periods of short-term pressure (e.g., economic crisis, liquidity problems), the transmission of the family firm's LTO into higher levels of EO, is put to a test. Although the patient capital provided by family ownership provides them the possibility to sustain entrepreneurial, managers must ensure that that the firm remains committed toward putting their LTO into practice. Indeed, the impact of short-term pressure may reduce managerial commitment towards implementing the firm's LTO. Even more, when managers do not agree on how to react to situations in which improving short-term results is of particular importance, it may stimulate conflict, regardless of size and composition of the management team.

Although not all conflict is inherently bad [69], the co-mingling of business and family roles and its corresponding tension in time orientation, can reduce commitment and encourage relationship conflict in the management team. Relationship conflict often engenders negative emotions like anger, resentment, and worry [70]. Even more, relationship conflict is known to diminish a family firm's attention towards business needs [71]. Therefore, the way in which managers interact may affect the relationship between LTO and EO in private family firms. For example, when a family firm whose dominant logic is focused on the long-run is confronted with situation were short-term pressure is high, this can induce relational conflicts between different members of the management team. Namely, 
family firms continuously need to balance their LTO with competing time pressures that follow from day-to-day operations in the management team [10]. Even among family firms that are characterized by an LTO, situations surrounding intertemporal choices often make it difficult to maintain and implement their LTO $[10,72]$ as a resource for EO.

To reduce these potential conflicts and ensure that managers remain committed towards putting the firm's LTO into practice, participative decision making (PDM) can serve as a moderating mechanism in the LTO-EO relationship. PDM is seen as the extent to which important strategic and operating decisions are made through consensus seeking versus individualistic or autocratic processes by the formally responsible executive [15]. Chirico et al. [67] state it as follows: PDM "is needed as a coordinating mechanism not only to avoid conflict and poor information flows accompanying increased generational involvement, but also to ensure employees' cooperation and commitment to the mobilizing vision" (p. 308). Thus, it is known that PDM reduces relational conflict and is especially relevant in the context of family firms where business goals, family goals, and personal goals continuously need to be balanced [19]. Also, PDM ensures that strategic decisions are made through consensus which creates greater organizational commitment and motivation [71]. Furthermore, PDM can be seen as integrative mechanism that allows individual managers to better grasp where the firm is headed (LTO), it can diminish managers' personal biases and enhance goal convergence [73]. Whereas continuous interaction among managers is beneficial in general [74], a participative atmosphere is especially necessary in the context of family firms, irrespective of the composition of the management team [69]. Hence, following the idea of resource orchestration, family firms can benefit from PDM as a coordinating mechanism that helps to translate LTO into EO.

The amount of decision-making power CEOs are willing to share with their subordinates is an important area of scholarly research. Opposed to participative decision making, autocratic leadership is defined as a particular style of leadership where all power and authority are concentrated in a single dominant leader [75-77] which creates a clearly defined intrateam hierarchy [78]. Although autocratic leadership was found to be beneficial for team climate under certain specific conditions (e.g., when speed in decision making is necessary [79]), researchers agree on the fact that it generally hurts group functioning when used consistently [78,80-83]. Namely, power centralization at the hierarchical CEO-level may lead employees to feel unwanted and underappreciated $[84,85]$ and may finally hinder team climate and team performance [78]. These dynamics, as a result of centralized leadership, are expected to cultivate conflict [83], thereby harming the family members' ability to communicate openly [86], preventing them to translate the dominant coalition's LTO into higher levels of EO. Furthermore, from an agency perspective, autocratic leaders have easier access to the pursuit of personal interest (e.g., short term gains) as they are able to bypass certain hierarchical barriers [87], which might be in conflict with the dominant coalition's ambition to translate their LTO into higher levels of entrepreneurship.

In sum, PDM can be seen as a moderating variable that strengthens the LTO-EO relationship by enhancing managerial commitment [18] and reducing potential relational conflicts among managers [19]. Hence, we postulate that the interaction of LTO and higher levels of PDM will positively affect a family firm's EO. Formally:

Hypothesis 2. A family firm's participative decision-making moderates the positive effect of long-term orientation on entrepreneurial orientation such that the relationship is more positive when participative decisionmaking increases.

A visual overview of the research framework and respective hypotheses can be found in Figure 1. 


\section{Materials and Methods}

\subsection{Sample}

The sample was taken in the 2012-2013 period from a broader survey exploring succession and governance matters in private family firms in Flanders, which is the northern part of Belgium. Based on the Belfirst database of Bureau van Dijk, we identified privately-owned firms located in the Flemish part of Belgium. Unfortunately, the Belfirst database does not cover genuine information on family ownership. Instead, four ex ante criteria regarding owner and board characteristics, which are available in the Belfirst database, were used in order to recognize potential family firms. As such, firms were classified as ex ante family firms if one or more of the following criteria apply to the firm: (1) the name of one of the directors is part of the firm name, (2) at least 2 directors have the same surname, (3) one of the directors lives at the same address as the firm, or (4) at least 2 directors live at the same address. This approach resulted in 3600 'potential' family firms, all which we contacted. The first survey was sent in December 2012. After two months, a reminder was sent in February 2013. We finalized our data collection in March 2013.

Family business scholars have been using a diversity of proxies to identify a family firm (e.g., [28,42]). This paper uses the generally accepted criteria of ownership and management control [88] and CEO's perception of being a family firm [89] to select an operational ex post definition of family firms. Accordingly, we classify a firm as a family firm if (1) at least 50 per cent of the shares are owned by the family, the company is family managed or the family is responsible for the strategic choices or succession decisions, or (2) at least 50 per cent of the shares are owned by the family, the company is not family-managed but the CEO perceives the firm as a family firm.

After sending a survey to all 3600 ex ante family firms, we received 452 surveys which resulted in a response rate of 12.5 percent. In our final sample we excluded firms that employed less than 5 people $(n=23)$ and we deleted firms where the management team only contained one single manager $(n=55)$ because in this type of firms PDM is not relevant. Furthermore, after the deletion of cases with missing values on relevant variables $(n=131)$ and non-family firms $(n=34)$, we maintained an ultimate sample of 209 cases. The response rate of $12.5 \%$ is consistent with previous studies on privately held firms, including studies on EO and private firms in Belgium e.g. [90-92]. Furthermore, a review of prior work on EO and innovation in SMEs revealed that our sample size and response rate are in line with research published in leading entrepreneurship journals e.g. [2,93,94]. According to Belfirst-Bureau Van Dijk database that collects and reports financial statements of all Belgian firms, there were approximately 29.000 companies in Flanders with more than 5 employees in 2013. Since, approximately $77 \%$ of all Flemish firms are family firms [92], we end up with a population of approximately 22,000 family firms with more than 5 employees. Taking into account a confidence level of $95 \%$ and a sample size of 209 family firms, this results in an acceptable margin of error of $6.75 \%$

Correlations of the study's variables are presented in Table 1, supplementary descriptions can be found in Table 2. 
Table 1. Correlation table.

\begin{tabular}{|c|c|c|c|c|c|c|c|c|c|c|c|c|c|}
\hline & 1 & 2 & 3 & 4 & 5 & 6 & 7 & 8 & 9 & 10 & 11 & 12 & 13 \\
\hline 1. EO & 1.00 & & & & & & & & & & & & \\
\hline 2. LTO & $0.34^{* * *}$ & 1.00 & & & & & & & & & & & \\
\hline 3. PDM & $0.14^{* *}$ & $0.24^{* * *}$ & 1.00 & & & & & & & & & & \\
\hline 4.Firm Size (Ln employees) & -0.03 & 0.09 & 0.07 & 1.00 & & & & & & & & & \\
\hline 5. Manufacturing & 0.10 & 0.04 & 0.06 & 0.10 & 1.00 & & & & & & & & \\
\hline 6. Construction & $-0.17^{* *}$ & -0.04 & -0.08 & -0.02 & $-0.34^{* * *}$ & 1.00 & & & & & & & \\
\hline 7. Wholesale & 0.08 & 0.10 & 0.03 & -0.04 & $-0.30^{* * *}$ & $-0.23 * * *$ & 1.00 & & & & & & \\
\hline 8. Retail & $0.12 *$ & -0.04 & -0.03 & -0.04 & $-0.22^{* * *}$ & $-0.17^{* *}$ & $-0.15^{* *}$ & 1.00 & & & & & \\
\hline 9. Past Performance & -0.04 & -0.03 & 0.09 & 0.03 & -0.11 & 0.10 & -0.00 & 0.04 & 1.00 & & & & \\
\hline 10. Liquidity & $-0.17^{* *}$ & $-0.12 *$ & $-0.12 *$ & -0.09 & -0.01 & $0.12 *$ & -0.05 & -0.03 & $0.13 *$ & 1.00 & & & \\
\hline 11.Presence of Non-family Manager & $0.27^{* * *}$ & $0.23^{* * *}$ & $0.22 * * *$ & $0.34^{* * *}$ & $0.17^{* *}$ & $-0.17^{* *}$ & 0.03 & -0.03 & 0.04 & $-0.19 * *$ & 1.00 & & \\
\hline 12. Size Management Team (Ln) & $0.17^{*}$ & 0.09 & $0.16^{* *}$ & $0.34^{* * *}$ & $0.12 *$ & $-0.12 *$ & 0.00 & -0.023 & 0.02 & 0.06 & $0.62 * * *$ & 1.00 & \\
\hline 13. Generation in Management & 0.06 & 0.02 & -0.11 & $-0.12 *$ & 0.04 & 0.05 & $-0.12 *$ & 0.00 & $-0.12 *$ & $-0.13 *$ & -0.00 & -0.04 & 1.00 \\
\hline
\end{tabular}

$*, * * * * *$ Significance at 0.100 .05 and 0.01 , respectivel; long-term orientation (LTO), entrepreneurial orientation (EO) and participative decision-making (PDM). 
Table 2. Descriptive Statistics.

\begin{tabular}{|c|c|c|c|c|c|}
\hline & & Minimum & Maximum & Mean & Standard Error \\
\hline \multicolumn{2}{|l|}{ EO (9-63) } & 12 & 56 & 35.88 & 9.41 \\
\hline \multicolumn{2}{|l|}{ LTO (3-21) } & 3 & 21 & 11.79 & 3.95 \\
\hline \multicolumn{2}{|c|}{ PDM (5-35) } & 11 & 35 & 22.45 & 4.48 \\
\hline \multicolumn{2}{|c|}{ Number of Employees } & 5 & 261 & 30.58 & 29.16 \\
\hline \multicolumn{2}{|c|}{ Past Performance (ROA) } & -25.39 & 36.78 & 5.21 & 7.61 \\
\hline \multicolumn{2}{|c|}{ Liquidity (Current Ratio) } & 0.23 & 29.45 & 2.55 & 3.37 \\
\hline \multicolumn{2}{|c|}{ Size of the Management Team } & 2 & 15 & 3.43 & 1.84 \\
\hline \multicolumn{6}{|c|}{ Percentage of observations } \\
\hline \multirow{2}{*}{ Presence of Non-family Manager } & Yes & \\
\hline & No & & & & \\
\hline \multirow{2}{*}{ Generation in Management } & Founding Family & \multicolumn{4}{|c|}{$\begin{array}{l}57.89 \% \\
33.01 \%\end{array}$} \\
\hline & Later Generations & \multicolumn{4}{|c|}{$66.99 \%$} \\
\hline \multirow{5}{*}{ Firm Industry } & Manufacturing & \multicolumn{4}{|c|}{$30.62 \%$} \\
\hline & Construction & \multicolumn{4}{|c|}{$20.57 \%$} \\
\hline & Wholesale & \multicolumn{4}{|c|}{$16.75 \%$} \\
\hline & Retail & \multicolumn{4}{|c|}{$10.05 \%$} \\
\hline & Services & \multicolumn{4}{|c|}{$22.01 \%$} \\
\hline
\end{tabular}

Long-term orientation (LTO), entrepreneurial orientation (EO) and participative decision-making (PDM).

\subsection{Variables and Measures}

Entrepreneurial Orientation. We used the 9-item Miller/Covin and Slevin [95] scale to measure the family firm's EO. This scale includes 3 sub-dimensions (innovation, proactiveness, and risk taking), all consisting of 3 separate items. The 9-item Miller/Covin and Slevin [95] scale is a reflective measure of EO, which means that $\mathrm{EO}$ is empirically defined in terms of the common variance among the indicators [96]. This is in line with our theoretical conceptualization of EO where we defined $\mathrm{EO}$ as the concurrent exhibition of innovativeness, risk-taking, and proactiveness [1,95]. This is important as ongoing debates in EO literature have emphasized the need for consistency among the empirical operationalization and the theoretical conceptualization of the EO [97]. Thus, entrepreneurial firms are those that demonstrate innovativeness (i.e., the introduction of new products, processes, and business models), proactiveness (i.e., actively entering new product/market spaces and seeking market leadership positions), and risk taking (i.e., a willingness among strategic decision makers to contribute resources to projects with uncertain outcomes). Also, the 9-item Miller/Covin and Slevin [95] scale is generally accepted as the most widely used (reflective) EO measure and has proven to be highly valid and reliable $[97,98]$. In our study, the underlying EO dimensions were strongly correlated and the calculated Cronbach's alpha for EO was 0.89, which is good for exploratory research [99].

Long-term orientation. LTO refers to a family firm's propensity to prioritize the long-range effects and impact of decisions and actions that come to fruition after a longer time period [6]. A family firm's orientation towards time is reflected in its choice of control system. Financial controls emphasize a short-term orientation [54] whereas strategic controls reinforce a long-term orientation [3]. Financial controls are often based on objective performance quotas like cash flow or return on investment. Strategic controls, on the other hand, are mostly based on soft performance indicators like for example customer satisfaction, or informal face-to-face meetings with managers. In line with recent operationalizations of the LTO construct [52,53], we measure a family firm's LTO using Zahra et al.'s [3] operationalization. In our study, the Cronbach's alpha for LTO was 0.74 , which is also adequate for exploratory research [99]. Scale items can be found in Appendix A. Next, we validated our LTO measure using convergent validity. Convergent validity refers to the extent to which endeavors to measure the same concept with different methods are in agreement [100]. Given that R\&D expenses have been previously used as a proxy for LTO because they are characterized by large upfront payments and deferred returns $[17,101]$, we look at the correlation between the measure of LTO [3] and the firm's commitment to R\&D, technological leadership, and innovation (a single item in our database, 
measured on a seven-point Likert scale), and find a positive correlation $(0.2644, p<0.01)$. Since LTO and firm's commitment to R\&D, technological leadership, and innovation are not measurements of the exact same construct, we do not expect correlations to be extremely high but rather in the fair or moderate range, as suggested by Gregory [102]. Hence, a significant correlation of 0.2644 is in the range we were expecting. To establish discriminant validity, we ran a principal component factor analysis on Zahra's LTO items together with four items representing a short-term orientation (STO), all on a seven-point Likert scale [3] (i.e., "To what extent are the following used in managing and evaluating your company's performance? (1) Cash flow; (2) return on investment; (3) objective criteria, such as return on assets; (4) formal performance appraisal"). Here, we expect that dissimilar constructs (or items), like LTO and STO, should load on other factors. The principal component factor analysis resulted in two factors with an eigenvalue greater than one, where LTO and STO items loaded on separate factors. Taken together, both convergent and discriminant validity tests support the construct validity of our LTO measure.

Participative decision making. In the current study, PDM was defined as the degree to which the firm's main strategic and operating decisions are made through consensus seeking versus individualistic or autocratic processes by the formally responsible executive [15]. In line with this definition, we used Covin et al.'s [15] five-item scale to capture the PDM construct. The Cronbach's alpha for PDM in our study is 0.70 , which is also sufficient for exploratory studies [99]. Scale items can be found in Appendix A.

Control variables. To guarantee proper model specification, we incorporated numerous control variables in our model. In particular, we control for several firm characteristics that could influence the link between LTO and EO: firm size, firm industry, past performance, liquidity, the presence of a non-family manager in the management team, the size of the management team, and the generation that is currently involved in the management of the firm. Firm size e.g. [3,103-105] was measured as the natural logarithm of the number of full-time employees; firm industry e.g. $[3,103,105]$ was measured using four dummy variables that differentiate between 5 major business lines: manufacturing, construction, wholesale, retail, and services; past performance e.g. $[3,91,101,105,106]$ was measured as the 3-year ROA average (2010-2012); liquidity e.g. [3,50,105,107,108] was measured as the 3-year average of the firm's current ratio (2010-2012); the presence of a non-family manager e.g. [109] in the management team was measured using a dummy variable that equals one when there is a non-family manager present in the management team and zero otherwise. We control for the presence of a non-family manager because this may affect the degree of relationship conflict in family firms [69] and as a consequence it may ultimately affect the LTO-EO relationship. In addition, we control for potential relationship conflict by including the size of the management team as a control variable e.g. [110-112], measured as the natural logarithm of the number of managers in the management team. Also, we control for the generation that is currently active in the management of the firm e.g. $[106,109,113]$ by creating a dummy variable that equals one when the management is in hands of the founding family and zero when later generations are involved in the management of the firm. We control for this generation effect because it may influence the LTO-EO relationship by inducing relationship conflict in family firms $[19,69]$. Control variables were drawn from either the survey or the Belfirst database of Bureau van Dijk which covers more than 1.2 million Belgian companies. We used the company name to link the data of our questionnaire with the financial statements of the Bureau van Dijk database.

Collecting data from the same data source can result in common method bias problems. Namely, when all variables in the model are entered in an unrotated factor analysis and only a small number of factors emerge with one primary factor accounting for the majority of variance among the variables, common method bias is a found to be a significant problem [114]. First, to check if common method bias is a substantial concern in our study, we executed the Harman's single-factor test [115]. We entered all relevant variables into an unrotated factor analysis, which resulted in six factors with eigenvalues $>1$. None of the single factors explained more than $32 \%$ of variance in the data. While this analysis does 
not fully eliminate the possibility of common method bias, it minimizes our concern for a common method factor. Second, we estimated an unmeasured latent method factor model on the three latent variables of our research model for which common method bias might be an issue (LTO, PDM and EO) $[114,116]$. The results of this test showed a common factor value of -0.216 which represents a common variance of 4.7 per cent $\left(-0.216^{2}\right)$. Third, we used a common marker variable technique [117]. In doing so, we selected a latent variable in our data that could be used as a possible marker variable for this test. More specifically, we use "psychological ownership" (PO) as a marker variable. PO is referred to as a condition in which individuals feel as though the target of ownership (material or immaterial in nature) or a piece of it is "theirs" (in other words, "It is MINE!") or "ours" (in other words, "It is OURS!") [118]. To capture the CEO's PO, we use the seven-item Likert scale created by Van Dyne and Pierce [119]. PO items were not (for EO and LTO) or only weakly (for PDM) correlated with our focal variables and are supposed to share potential common method variance [116,120]. This analysis shows a common factor value of 0.372 and a common variance of only $13.8 \%$ per cent $\left(0.372^{2}\right)$. Finally, as recommended by Podsakoff et al. [114] we also designed our survey by taking into account several procedural remedies (e.g., psychological separation of measurement and counterbalancing question order) to minimize the concern for a common method factor. Taken together, common method bias is not a main concern in our study.

\section{Results}

The average family firm in our sample employed 30.58 employees and 3.43 managers. In 42.11 percent of the cases a non-family member was present in the management team and approximately two thirds $(66.99 \%)$ of the sample was managed by second or later generation family members. Table 1 further elaborates on the correlations and Table 2 provides the descriptive statistics of the variables included in our model. The correlations were moderate and did not indicate multicollinearity problems in our sample. However, it seems that having an LTO is positively associated with $\mathrm{EO}(\mathrm{r}=0.3399, p<0.01)$, which is a preliminary indication that a family firm's LTO can serve as a resource for their EO.

Although regressions models and structural equation modeling (SEM) have both advantages and disadvantages, moderation regression models are much easier to estimate and interpret than moderation SEM [121,122]. Therefore, and in line with seminal EO research, we analyze our model using robust linear regression analysis e.g., [67,90,91]. Before running all robust linear regression analyses, we tested the measurement model including the latent variables used in our study (EO, LTO and PDM). This model achieved an acceptable fit $(\chi 2[116]=438.98, p=0.000$, SRMR $=0.069$, RMSEA $=0.093)$, indicating that the factorial structure of these variables is satisfactory $[99,123,124]$. When we calculate the same fit indices for our baseline two-factor model (LTO-EO), we get the following results: $\chi^{2}[53]=319.22, p=0.000, \mathrm{SRMR}=0.063$, RMSEA $=0.125$. Although the results of our two-factor model are still acceptable, the comparison with our three-factor model provides evidence of construct distinctiveness for EO, LTO and PDM. Since the three-factor model fitted the data better than the two-factor model, we can also support the discriminant validity of the constructs.

To provide empirical evidence for our study's hypotheses, we tested two different models using robust linear regression analysis. Table 3 shows the results of these models where the first model is used to test our first hypothesis. Namely, to test the effect of a family firm's LTO on their level of EO, we used the following regression model:

$$
\mathrm{EO}=\alpha+\beta_{1} \mathrm{LTO}+\delta \text { Controls }+\varepsilon .
$$


Table 3. Robust linear regression analysis, 2 Models.

\begin{tabular}{|c|c|c|c|c|c|}
\hline \multirow{2}{*}{\multicolumn{2}{|c|}{ Dependent Variable: EO }} & \multicolumn{2}{|c|}{ Model 1} & \multicolumn{2}{|c|}{ Model 2} \\
\hline & & \multirow[t]{2}{*}{$\beta$} & \multirow[t]{2}{*}{ S.E. } & \multirow[t]{2}{*}{$\beta$} & \multirow[t]{2}{*}{ S.E. } \\
\hline Controls & Firm Characteristics & & & & \\
\hline & Firm size & $-1.7380 * *$ & 0.8281 & $-1.7177^{* *}$ & 0.8008 \\
\hline & Past performance & -0.0135 & 0.0797 & -0.0176 & 0.0761 \\
\hline & Liquidity & -0.2521 & 0.1607 & -0.2432 & 0.1601 \\
\hline & $\begin{array}{c}\text { Presence of non-family } \\
\text { manager }\end{array}$ & $3.3394 * *$ & 1.6707 & $3.1100 *$ & 1.6482 \\
\hline & Size management team & 1.3227 & 1.7606 & 1.3733 & 1.7282 \\
\hline & $\begin{array}{c}\text { Generation in management } \\
\text { Industry }{ }^{\text {a }}\end{array}$ & 0.6629 & 1.3164 & 0.7011 & 1.2565 \\
\hline & Manufacturing & 2.2624 & 1.8174 & 2.2022 & 1.7409 \\
\hline & Construction & -0.6976 & 1.8910 & -0.4987 & 1.8345 \\
\hline & Wholesale & 2.2919 & 1.9744 & 2.1195 & 1.8847 \\
\hline & Retail & $5.0813^{* *}$ & 2.2967 & $4.6508^{* *}$ & 2.2412 \\
\hline \multicolumn{6}{|l|}{ Hypothesis } \\
\hline & LTO & $0.6821^{* * *}$ & 0.1600 & $0.7066^{* * *}$ & 0.1650 \\
\hline & PDM & & & 0.0359 & 0.1393 \\
\hline & LTO*PDM & & & $0.0575^{*}$ & 0.0334 \\
\hline $\mathrm{R}^{2}$ & & \multicolumn{2}{|c|}{0.2199} & \multicolumn{2}{|c|}{0.2320} \\
\hline $\mathrm{F}$ & & \multicolumn{2}{|c|}{$6.04^{* * *}$} & \multicolumn{2}{|c|}{$6.03^{* * *}$} \\
\hline
\end{tabular}

$\mathrm{N}=209,{ }^{* * * * * * *}$ Significance at 0.100 .05 and 0.01 , respectively. ${ }^{a}$ suppressed category for the firm's industry is "services". Dependent variable: entrepreneurial orientation (EO). Independent variable: long-term orientation (LTO). Moderating variable: participative decision-making (PDM).

Results show that the estimated model was significant $(p<0.01)$ and it seems that firm size $(\beta=-1.7380, p<0.05)$, the presence of a non-family manager $(\beta=3.3394, p<0.05)$, and the retail sector $(\beta=5.0813, p<0.05)$ are the only control variables that significantly affect the level of EO in private family firms. Furthermore, results from the regression analysis in Model 1 show that a family firm's LTO was significantly associated with their level of $\mathrm{EO}(\beta=0.6821, p<0.01)$, which provides support for our first hypothesis.

After finding support for the direct LTO-EO relationship, we conducted an additional regression analysis, to test our second hypothesis. Specifically, to test the moderating effect of PDM on the LTO-EO relationship, we tested the following equation in Model 2:

$$
\mathrm{EO}=\alpha+\beta_{1} \mathrm{LTO}+\beta_{2} \mathrm{PDM}+\beta_{3} \mathrm{LTO}^{*} \mathrm{PDM}+\delta \text { Controls }+\varepsilon .
$$

To test this interaction effect, we mean-centered the interaction terms to minimize multicollinearity problems [125]. Inspection of the variance inflation factors (VIFs) showed that multicollinearity was not a concern. All VIF coefficients were lower than two [126]. An examination of the second model reveals some interesting results. Namely, Hypothesis 2 argues that LTO and PDM interact to positively affect a family firm's EO. As seen in Model 2, the interaction term (LTO*PDM) was positive and statistically significant $(\beta=0.0575, p<0.10)$. Thus, Hypothesis 2 is weakly supported.

Nevertheless, it might be the case that the interaction effect is not significant between certain values of the moderating variable and strongly significant for another range of the moderating variable [25,127]. For example, it might be possible that family firms require a minimum level of PDM in order for an LTO to support EO. Therefore, we performed an additional analysis where we calculate the marginal effect of LTO on EO. As can be seen in the following equation:

$$
\frac{\partial \mathrm{EO}}{\partial \mathrm{LTO}}=\beta_{1}+\beta_{3} \mathrm{PDM}
$$


The marginal effect of LTO on EO is dependent on the level of PDM. By taking into account the relevant elements of the variance-covariance matrix and recalculating the standard errors as suggested by Brambor, Clark, and Golder [25], we calculated the marginal effect of LTO on EO. The solid line in Figure 2 clearly shows the marginal effect of LTO on EO. The dotted lines above and below the solid line represent the $95 \%$ confidence interval. This $95 \%$ confidence interval is essential to consider the conditions under which LTO has a statistically significant effect on EO. Thus, the marginal effect of LTO on EO is only significant when both dotted lines are above (or below) the zero line. At this point, it is clear that LTO only has a significant positive effect on a family firm's EO when PDM is equal or higher than 18. Conversely, when PDM is lower than 18, LTO no longer affects EO. Looking at our sample, we see that the majority of family firms $(84.7 \%)$ are characterized by a PDM level that is higher or equal to 18. Taken together, a minimum level of PDM is necessary to translate an LTO into higher levels of EO which is in line with the argument of resource orchestration.

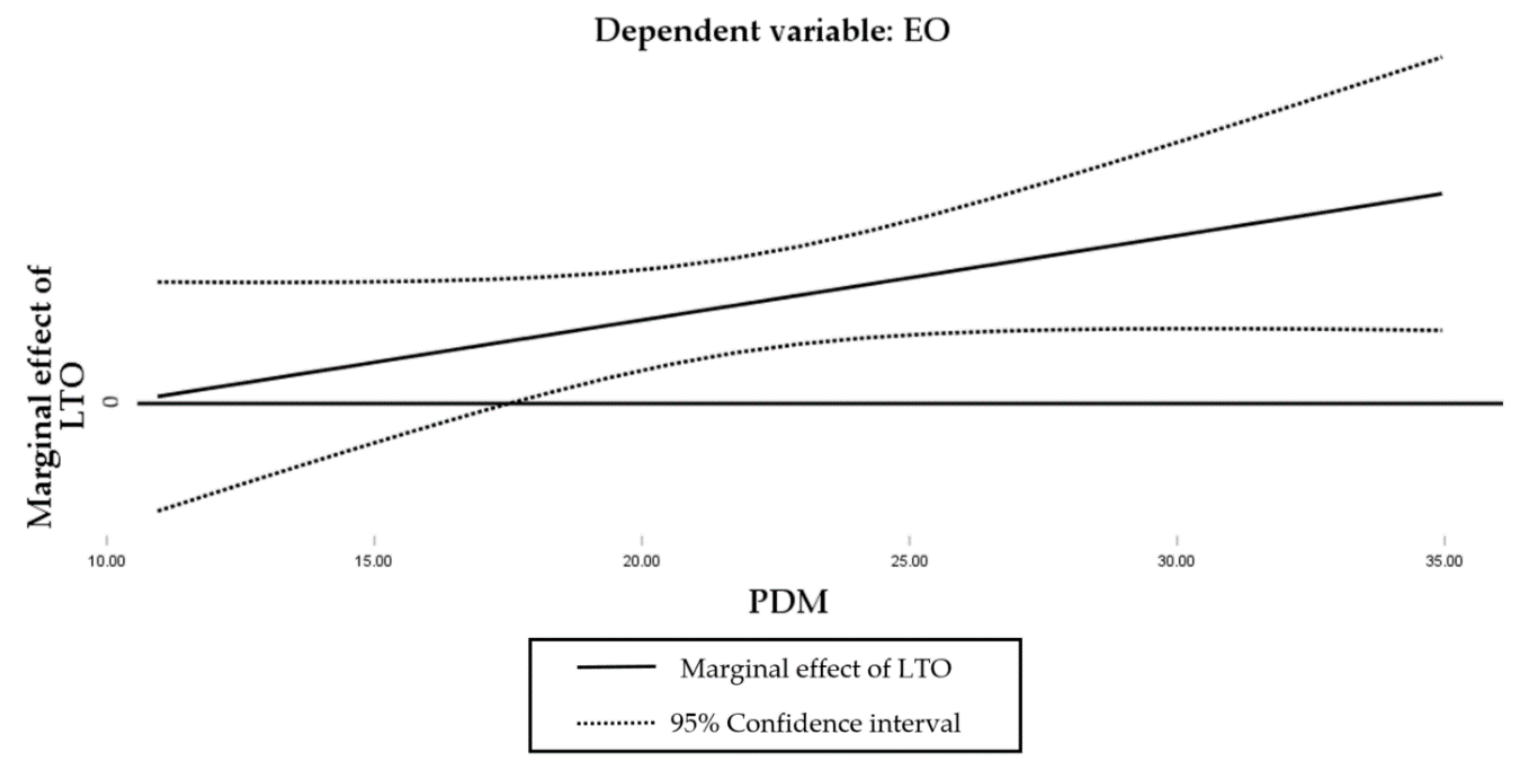

Figure 2. Marginal effect of LTO on a family firm's EO as PDM changes. Note: percentage distribution of the PDM variable: PDM values $5-17=15.31 \%$ of the sample; PDM values $18-35=84.7 \%$ of the sample.

\section{Discussion}

A family firm's LTO is a potential strategic resource that family firms can exploit to attain a sustained competitive advantage by increasing their EO. Applying the RBV of the firm, Zahra et al. [3] found evidence for this direct relationship. Our study elaborates the work of Zahra and his colleagues by investigating how this LTO is translated into higher levels of EO. Namely, the findings of this paper suggest that LTO is only connected to EO when there is a minimal degree of PDM in the family firm. Consequently, when decision making processes in the family firm are illustrated by low levels of PDM, LTO no longer affects EO. This is in line with our central reasoning and supports the idea of resource orchestration which posits that managers should leverage the resources at hand. Namely, merely having an LTO is not enough to result in higher levels of EO; instead, managers should create mechanisms that ensure different opinions are taken into account in order to reduce rancorous conflict and isolation between different business units [67]. Hence, the relationship between LTO and EO seems to be contingent on PDM, as this decision-making style reassures that decision makers share their individual thoughts and believes which boosts knowledge sharing, nurtures commitment and constructive discussions, while at the same time reducing potential relational conflicts. Conversely, our results do not imply that family firms with powerful CEOs cannot be successful. Prior literature has recognized the importance of CEO power [128] in family firms and the way in which it can 
successfully influence their strategic decision making. Nevertheless, our results indicate that an autocratic decision-making style (i.e., low PDM) is not supportive for the transmission of a family firm's LTO into higher levels of EO. Also, our study focused on private family firms of a certain size, employing at least five people and having a management team of at least two senior managers, which makes it more likely for relational conflict to prevail and reinforces the need for PDM.

Interestingly, our conclusions parallel the findings of Lumpkin et al. [6] who theoretically explored the degree to which family businesses can be entrepreneurial given an LTO. However, their study conceptualizes EO as a multidimensional construct where the underlying dimensions are allowed to vary independently $[129,130]$. Although their conceptualization of EO is different from the composite dimension approach $[1,95]$ we apply in our paper, neither approach is superior to the other [96]. By introducing PDM into this debate, our study contributes to their theoretical framework. Indeed, our paper empirically shows that PDM, as a conflict management style, moderates the relationship between LTO and EO by reducing potential relational conflicts. Our paper mainly focused on the dark side of conflict (relational), because it is especially the dark side that influences the mechanism that translates LTO in EO. Nevertheless, conflict also seems to have a bright side $[69,131]$ but these conflict types (e.g., task and process conflict) are fundamentally different in nature an do not affect the LTO-EO relationship.

Also, using LTO as a temporal perspective [132-134], we contribute to an emerging research stream discovering the drivers of firm-level decision-making processes $[135,136]$. Although a temporal perspective is generally acknowledged as a fundamental paradigm in strategic management research, only a small number of studies have empirically scrutinized how LTO affects strategic decision-making processes. Recently, Lin et al. [24] found that having an LTO is beneficial for the richness, speed, and creativity of strategic decision-making processes. As EO originally stems from strategic management literature $[137,138]$ our study contributes to this emerging research stream investigating the effects of temporal orientations on strategic decision-making processes [139]. Moreover, introducing $\mathrm{PDM}$ as a moderating mechanism into the LTO-EO relationship, we answer Lin et al.'s recent call [24] to investigate how the hypothesized relationship between temporal orientation and strategic decision-making processes alters under changed types of decision making (e.g., autocratic vs. participative). In a broad sense, this study also contributes to the literature on "familiness" [39] of the firm. The familiness concept stems from the RBV and refers to "the idiosyncratic firm level bundle of resources and capabilities resulting from the systems interactions" [39] (p.451). Indeed, the interaction between the family- and the business system often creates the opportunity to be more long-term oriented [140]. Thus, an LTO can be seen as a potential resource for EO that stems from the familiness of the firm. Here, we do not suggest that all family firms have an LTO because the family business population is known to be a heterogeneous group [141,142]. In differentiating between different levels of LTO and PDM we recognize that family firms are a diverse group in terms of time orientation and decision making. As a consequence, merely having an LTO is not a sufficient qualification for a family firm to have higher levels of EO. Although there is a conviction in family business literature that family firms have a higher LTO than non-family firms $[35,37,143]$, future research may investigate to what extent our results might also apply to non-family firms.

Future research should also identify conditions under which the LTO-EO relationship becomes less straightforward. For example, environmental dynamism can complicate the LTO-EO relationship in such a way that family firms are more likely to take advantage of a short-term orientation rather than an LTO. Namely, hostile environments may force family firms to think quick and prioritize the short-term implications and impact of their decisions. Also, an investment opportunity may sometimes require a fast decision without careful deliberation concerning its long-term consequences [10]. In sum, other moderating variables may exist that can alter the relationship between a family firm's LTO and EO. Therefore, a more in-depth study of the association between a firm's time orientation and its level of EO is a highly desired future research area. 
For our independent variable LTO, there is little convergence among scholars about how to measure the construct $[6,9,144]$. Therefore, we have chosen to measure a family firm's time orientation using Zahra et al.'s [3] LTO scale because it best fits our research context. Since time preferences cannot be directly observed or measured, future research may benefit from the development of a more fine-grained LTO scale. Moreover, our study did not address the potential performance consequences of having an LTO. Although our study indicates that longer planning horizons stimulate entrepreneurial behavior, future research should further investigate the extent to which these efforts ultimately generate performance gains. Empirical research is needed to tease out the effect of temporality when studying the EO-performance relationship in private family firms. The call to investigate the sustainability of the EO-performance relationship was already launched in 1999 by Johan Wiklund [58]. In this light, a recent study by Hernández-Perlines and Nina Rung-Hoch [145] has shown that EO interacts with corporate social responsibility to affect family firm performance. It is self-evident that entrepreneurial activity that is driven by the desire to achieve long-term success might not only be considered with financial returns. Sustainable performance contains three dimensions that need to be taken into account: the economic dimension, the social dimension, and the environmental dimension [145-147]. Especially, family firms whose ultimate goal is to achieve long term survival must satisfy multiple stakeholders [148], including non-financial goals of family members, often referred to as "socioemotional wealth" $[28,36,37,149]$. Thus, besides the temporal component explored in our research, other family-related non-financial goals may intervene in the entrepreneurial process and eventually determine the sustainability of the EO-performance relationship.

Nonetheless, our study has an important implication for practice. We showed that family firms are very different when it comes to their orientation towards time, but in general their LTO provides them a potential resource to engage in entrepreneurship. Our results showed that an LTO is merely a potential resource of which managers should be aware when steering the family firm. Indeed, managers should actively try to engage all key individuals in the decision-making process in order to prevent that short-term pressures can evoke conflicts or threaten managerial commitment which may impede successful implementation of the family firm's dominant logic (LTO). Therefore, to avoid these potential drawbacks, managers in family firms should try to facilitate mechanisms that favor PDM.

This can be done by encouraging all family members to participate in discussions and express their point of views openly and candidly. Family firms can fully benefit of their LTO if they create an atmosphere where there is room for discussion, negotiation, and revision [150]. This might be a particular challenge in later generation family firms where older generations should be open to accept the knowledge and input of younger generations, and vice versa $[67,151]$. Also, between family members of the same generation and between family and non-family employees, mutual respect and interaction are key.

\section{Conclusions}

This study demonstrates that a family firm's time orientation is an important element in understanding firm-level entrepreneurship. Our findings suggest that having an LTO supports family firms in their entrepreneurial endeavors but an empirical analysis of the LTO-EO relationship shows that the manifestation of LTO is highly complex and dependent on the family firm's decision-making style. Hence, building on RBV and resource orchestration theory, our main contribution has been to position LTO as a potential resource for entrepreneurial family firms. The results of our analyses suggest that a family firm's LTO only results in higher levels of EO when a minimal level of PDM is achieved. In other words, when a family firm's dominant logic favors the long run, a participative decision-making style is necessary to transmit this temporal orientation into EO. Our results support the premise that PDM should be seen as a coordinating mechanism that strengthens the LTO-EO relationship by enhancing managerial commitment [18] and reducing potential relational conflicts among managers [19], especially when the family firm is faced with omnipresent short-term pressures. For example, the sudden death of a predecessor, liquidity constraints, or crisis management, are all 
short-term pressures that may dramatically challenge successful enactment of the family's dominant logic towards LTO. Therefore, to circumvent internal conflicts these short-term pressures might entail, family firms should try to facilitate mechanisms that favor PDM in order to grasp the full potential of their LTO.

Author Contributions: All authors attest to making substantial, direct, intellectual contributions to this research and approve of its publication. Conceptualization, J.S.; Data curation, J.S.; Formal analysis, J.S.; Methodology, J.S.; Writing-original draft, J.S.; Writing-review and editing, W.V., T.S. and E.L. All authors have read and agreed to the published version of the manuscript.

Funding: This research received no external funding.

Conflicts of Interest: The authors declare no conflicts of interest.

\section{Appendix A}

Here, we illustrate the exact items [3] that were used to proxy a family firm's orientation towards time expressed through their organizational culture [3]. All items followed a seven-point Likert scale ( $1=$ not used at all, $7=$ widely used $)$. A higher score on this scale indicates a higher level of LTO.

To what extent are the following used in managing and evaluating your company's performance? Please circle the one number that best describes your company's situation over the past 3 years.

- Formal face-to-face meetings among managers to discuss company performance

- Informal face-to-face meetings among managers to evaluate company goal achievements

- Evaluating company performance against subjective criteria such as customer satisfaction

Next, we illustrate the exact items [15] that were used to capture a family firm's PDM. All items followed a seven-point Likert scale ( $1=$ totally not agree, $7=$ fully agree). A higher score on this scale indicates a more PDM style.

To what extent do you agree with the following statements:

- Our major operating and strategic decisions result from consensus-oriented decision making

- Our major operating and strategic decisions are made by single individuals with responsibility in the decision area (reverse coded)

- Our business unit's philosophy is to involve all levels of management in major operating and strategic decisions

- Consensus seeking is a common and pervasive decision-making practice in my business unit

- Information and power are shared extensively in making decisions in my business unit.

\section{References}

1. Miller, D. The correlates of entrepreneurship in three types of firms. Manag. Sci. 1983, 29, 770-791. [CrossRef]

2. Kellermanns, F.W.; Eddleston, K.A. Corporate entrepreneurship in family firms: A family perspective. Entrep. Theory Pract. 2006, 30, 809-830. [CrossRef]

3. Zahra, S.A.; Hayton, J.C.; Salvato, C. Entrepreneurship in family vs. non-family firms: A resource-based analysis of the effect of organizational culture. Entrep. Theory Pract. 2004, 28, 363-381. [CrossRef]

4. Simsek, Z.; Heavey, C.; Veiga, J.F. The impact of CEO core self-evaluation on the firm's entrepreneurial orientation. Strateg. Manag. J. 2010, 31, 110-119. [CrossRef]

5. Miller, D.; Le Breton-Miller, I. Governance, social identity, and entrepreneurial orientation in closely held public companies. Entrep. Theory Pract. 2011, 35, 1051-1076. [CrossRef]

6. Lumpkin, G.T.; Brigham, K.H.; Moss, T.W. Long-term orientation: Implications for the entrepreneurial orientation and performance of family businesses. Entrep. Reg. Dev. 2010, 22, 241-264. [CrossRef]

7. LeBreton-Miller, I.; Miller, D. Why do some family businesses out-compete? Governance, long-Term orientations, and sustainable capability. Entrep. Theory Pract. 2006, 30, 731-746. [CrossRef]

8. Hoffmann, C.; Wulf, T.; Stubner, S. Understanding the performance consequences of family involvement in the top management team: The role of long-term orientation. Int. Small Bus. J. 2016, 34, 345-368. [CrossRef] 
9. Brigham, K.H.; Lumpkin, G.T.; Payne, G.T.; Zachary, M.A. Researching long-term orientation: A validation study and recommendations for future research. Fam. Bus. Rev. 2014, 27, 72-88. [CrossRef]

10. Lumpkin, G.T.; Brigham, K.H. Long-term orientation and intertemporal choice in family firms. Entrep. Theory Pract. 2011, 35, 1149-1169. [CrossRef]

11. Sirmon, D.G.; Hitt, M.A. Managing resources: Linking unique resources, management, and wealth creation in family firms. Entrep. Theory Pract. 2003, 27, 339-358. [CrossRef]

12. Wilson, N.; Wright, M.; Scholes, L. Family business survival and the role of boards. Entrep. Theory Pract. 2013, 37, 1369-1389. [CrossRef]

13. Lumpkin, G.; Dess, G.G. Strategy in family business: Recent findings and future challenges. In The Landscape of Family Business; Edward Elgar Publishing: Cheltenham, UK, 2013.

14. Barney, J. Firm resources and sustained competitive advantage. J. Manag. 1991, 17, 99. [CrossRef]

15. Covin, J.G.; Green, K.M.; Slevin, D.P. Strategic process effects on the entrepreneurial orientation-Sales growth rate relationship. Entrep. Theory Pract. 2006, 30, 57-81. [CrossRef]

16. Gentry, R.; Dibrell, C.; Kim, J. Long-Term Orientation in Publicly Traded Family Businesses: Evidence of a Dominant Logic. Entrep. Theory Pract. 2016, 40, 733-757. [CrossRef]

17. Kappes, I.; Schmid, T. The effect of family governance on corporate time horizons. Corp. Gov. Int. Rev. 2013, 21, 547-566. [CrossRef]

18. Huang, X.; Shi, K.; Zhang, Z.; Cheung, Y. The impact of participative leadership behavior on psychological empowerment and organizational commitment in Chinese state-owned enterprises: The moderating role of organizational tenure. Asia Pac. J. Manag. 2006, 23, 345-367. [CrossRef]

19. Eddleston, K.A.; Otondo, R.F.; Kellermanns, F.W. Conflict, participative decision-making, and generational ownership dispersion: A multilevel analysis. J. Small Bus. Manag. 2008, 46, 456-484. [CrossRef]

20. Filbeck, G.; Smith, L.L. Team building and conflict management: Strategies for family businesses. Fam. Bus. Rev. 1997, 10, 339-352. [CrossRef]

21. Harvey, M.; Evans, R.E. Family business and multiple levels of conflict. Fam. Bus. Rev. 1994, 7, 331-348. [CrossRef]

22. Hitt, M.A.; Ireland, R.D.; Sirmon, D.G.; Trahms, C.A. Strategic entrepreneurship: Creating value for individuals, organizations, and society. Acad. Manag. Perspect. 2011, 25, 57-75.

23. Sirmon, D.G.; Hitt, M.A.; Ireland, R.D. Managing firm resources in dynamic environments to create value: Looking inside the black box. Acad. Manag. Rev. 2007, 32, 273-292. [CrossRef]

24. Lin, Y.; Shi, W.; Prescott, J.E.; Yang, H. In the Eye of the Beholder: Top Managers' Long-Term Orientation, Industry Context, and Decision-Making Processes. J. Manag. 2019, 45, 3114-3145. [CrossRef]

25. Brambor, T.; Clark, W.R.; Golder, M. Understanding interaction models: Improving empirical analyses. Political Anal. 2006, 14, 63-82. [CrossRef]

26. Zellweger, T. Time horizon, costs of equity capital, and generic investment strategies of firms. Fam. Bus. Rev. 2007, 20, 1-15. [CrossRef]

27. Cirillo, A.; Pennacchio, L.; Carillo, M.R.; Romano, M. The antecedents of entrepreneurial risk-taking in private family firms: CEO seasons and contingency factors. Small Bus. Econ. 2019, 1-20. [CrossRef]

28. Gómez-Mejía, L.R.; Cruz, C.; Berrone, P.; De Castro, J. The bind that ties: Socioemotional wealth preservation in family firms. Acad. Manag. Ann. 2011, 5, 653-707. [CrossRef]

29. Basco, R.; Calabrò, A.; Campopiano, G. Transgenerational entrepreneurship around the world: Implications for family business research and practice. J. Fam. Bus. Strategy 2019, 10, 100249. [CrossRef]

30. Ward, J.L.; Aronoff, C.E. The power of patient capital. Nation's Bus. 1991, 79, 48.

31. Sharma, S.; Sharma, P. Patient Capital; Cambridge University Press: Cambridge, UK, 2019.

32. Memili, E.; Fang, H.C.; Koc, B.; Yildirim-Öktem, Ö.; Sonmez, S. Sustainability practices of family firms: The interplay between family ownership and long-term orientation. J. Sustain. Tour. 2018, 26, 9-28. [CrossRef]

33. Miller, D.; Le Breton-Miller, I. Managing for the Long Run: Lessons in Competitive Advantage from Great Family Businesses; Harvard Business Press: Brighton, MA, USA, 2005.

34. Pieper, T.M. Mechanisms to Assure Long-Term Family Business Survival: A Study of the Dynamics of Cohesion in Multigenerational Family Business Families; Peter Lang: Frankfurt, Germany, 2007.

35. Anderson, R.C.; Reeb, D.M. Founding-family ownership and firm performance: Evidence from the S\&P 500. J. Financ. 2003, 58, 1301-1327. 
36. Berrone, P.; Cruz, C.; Gomez-Mejia, L.R. Socioemotional wealth in family firms: Theoretical dimensions, assessment approaches, and agenda for future research. Fam. Bus. Rev. 2012, 25, 258-279. [CrossRef]

37. Gómez-Mejía, L.R.; Haynes, K.T.; Núñez-Nickel, M.; Jacobson, K.J.L.; Moyano-Fuentes, J. Socioemotional wealth and business risks in family-controlled firms: Evidence from spanish olive oil mills. Adm. Sci. Q. 2007, 52, 106-137. [CrossRef]

38. Covin, J.G.; Slevin, D.P. A conceptual model of entrepreneurship as firm behavior. Entrep. Theory Pract. 1991, 16, 7-25. [CrossRef]

39. Habbershon, T.; Williams, M. A resource-based framework for assessing the strategic advantages of family firms. Fam. Bus. Rev. 1999, 12, 1-25. [CrossRef]

40. Wernerfelt, B. A resource-based view of the firm. Strateg. Manag. J. 1984, 5, 171-180. [CrossRef]

41. Frank, H.; Kessler, A.; Rusch, T.; Suess-Reyes, J.; Weismeier-Sammer, D. Capturing the familiness of family businesses: Development of the family influence familiness scale (FIFS). Entrep. Theory Pract. 2017, 41, 709-742. [CrossRef]

42. Rutherford, M.W.; Kuratko, D.F.; Holt, D.T. Examining the link between "familiness" and performance: Can the F-PEC untangle the family business theory jungle. Entrep. Theory Pract. 2008, 32, 1089-1109. [CrossRef]

43. Zellweger, T.M.; Eddleston, K.A.; Kellermanns, F.W. Exploring the concept of familiness: Introducing family firm identity. J. Fam. Bus. Strategy 2010, 1, 54-63. [CrossRef]

44. Daspit, J.J.; Long, R.G.; Pearson, A.W. How familiness affects innovation outcomes via absorptive capacity: A dynamic capability perspective of the family firm. J. Fam. Bus. Strategy 2019, 10, 133-143. [CrossRef]

45. Tokarczyk, J.; Hansen, E.; Green, M.; Down, J. A resource-based view and market orientation theory examination of the role of "familiness" in family business success. Fam. Bus. Rev. 2007, 20, 17-31. [CrossRef]

46. Carney, M. Corporate governance and competitive advantage in family-controlled firms. Entrep. Theory Pract. 2005, 29, 249-265. [CrossRef]

47. Hanson, S.K.; Keplinger, K. The balance that sustains benedictines: Family entrepreneurship across generations. Entrep. Reg. Dev. 2020, 1-15. [CrossRef]

48. Ketchen, D.J., Jr.; Hult, G.T.M.; Slater, S.F. Toward greater understanding of market orientation and the resource-based view. Strateg. Manag. J. 2007, 28, 961-964. [CrossRef]

49. Edelman, L.F.; Brush, C.G.; Manolova, T. Co-alignment in the resource-performance relationship: Strategy as mediator. J. Bus. Ventur. 2005, 20, 359-383. [CrossRef]

50. Wiklund, J.; Shepherd, D. Entrepreneurial orientation and small business performance: A configurational approach. J. Bus. Ventur. 2005, 20,71-91. [CrossRef]

51. Su, Z.; Xie, E.; Wang, D. Entrepreneurial orientation, managerial networking, and new venture performance in China. J. Small Bus. Manag. 2015, 53, 228-248. [CrossRef]

52. Ling, Y.; López-Fernández, M.C.; Serrano-Bedia, A.M.; Kellermanns, F.W. Organizational culture and entrepreneurial orientation: Examination through a new conceptualization lens. Int. Entrep. Manag. J. 2019, 16, 1-29. [CrossRef]

53. Campos, H.M.; Valenzuela, F.A.A. The relationship between entrepreneurial orientation, time orientation and small business performance: An evidence from Mexico. Rev. Da Micro E Pequena Empresa 2013, 7, 48-63.

54. Zahra, S.A. Goverance, ownership, and corporate entrepreneurship: The moderating impact of industry technological opportunities. Acad. Manag. J. 1996, 39, 1713-1735. [CrossRef]

55. Zahra, S.A.; Hayton, J.C.; Neubaum, D.O.; Dibrell, C.; Craig, J. Culture of family commitment and strategic flexibility: The moderating effect of stewardship. Entrep. Theory Pract. 2008, 32, 1035-1054. [CrossRef]

56. Rousseau, D. Psychological Contracts in Organizations: Understanding Written and Unwritten Agreements; Sage Publications: Thousand Oaks, CA, USA, 1995.

57. Meyer, J.P.; Allen, N.J. A three-component conceptualization of organizational commitment. Hum. Resour. Manag. Rev. 1991, 1, 61-89. [CrossRef]

58. Wiklund, J. The sustainability of the entrepreneurial orientation-performance relationship. Entrep. Theory Pract. 1999, 24, 39-50. [CrossRef]

59. Miller, D.; Xu, X. CEO long-term orientation and elite university education. Strateg. Organ. 2019. [CrossRef]

60. Leifer, R.; McDermott, C.M.; O’Connor, G.C.; Peters, L.S.; Rice, M.P.; Veryzer, R.W., Jr. Radical Innovation: How Mature Companies Can Outsmart Upstarts; Harvard Business Press: Brighton, MA, USA, 2000.

61. Zheng, W.; Shen, R.; Zhong, W.; Lu, J. CEO Values, Firm Long-Term Orientation, and Firm Innovation: Evidence from Chinese Manufacturing Firms. Manag. Organ. Rev. 2019, 16, 1-38. [CrossRef] 
62. Laforet, S. Effects of organisational culture on organisational innovation performance in family firms. J. Small Bus. Enterp. Dev. 2016, 23, 379-407. [CrossRef]

63. Sirmon, D.G.; Hitt, M.A.; Ireland, R.D.; Gilbert, B.A. Resource orchestration to create competitive advantage: Breadth, depth, and life cycle effects. J. Manag. 2011, 37, 1390-1412. [CrossRef]

64. Kraaijenbrink, J.; Spender, J.-C.; Groen, A.J. The resource-based view: A review and assessment of Its critiques. J. Manag. 2010, 36, 349-372. [CrossRef]

65. Ndofor, H.A.; Sirmon, D.G.; He, X. Firm resources, competitive actions and performance: Investigating a mediated model with evidence from the in-vitro diagnostics industry. Strateg. Manag. J. 2011, 32, 640-657. [CrossRef]

66. Sirmon, D.G.; Gove, S.; Hitt, M.A. Resource management in dyadic competitive rivalry: The effects of resource bundling and deployment. Acad. Manag. J. 2008, 51, 919-935. [CrossRef]

67. Chirico, F.; Sirmon, D.G.; Sciascia, S.; Mazzola, P. Resource orchestration in family firms: Investigating how entrepreneurial orientation, generational involvement, and participative strategy affect performance. Strateg. Entrep. J. 2011, 5, 307-326. [CrossRef]

68. Bertrand, M.; Schoar, A. The role of family in family firms. J. Econ. Perspect. 2006, 20, 73-96. [CrossRef]

69. Kellermanns, F.W.; Eddleston, K.A. Feuding families: When conflict does a family firm good. Entrep. Theory Pract. 2004, 28, 209-228. [CrossRef]

70. Jehn, K.A.; Mannix, E.A. The dynamic nature of conflict: A longitudinal study of intragroup conflict and group performance. Acad. Manag. J. 2001, 44, 238-251.

71. Eddleston, K.A.; Kellermanns, F.W. Destructive and productive family relationships: A stewardship theory perspective. J. Bus. Ventur. 2007, 22, 545-565. [CrossRef]

72. Thaler, R.H. From homo economicus to homo sapiens. J. Econ. Perspect. 2000, 14, 133-141. [CrossRef]

73. Ketokivi, M.; Castañer, X. Strategic planning as an integrative device. Adm. Sci. Q. 2004, 49, 337-365.

74. Thomas, J.A.; McDaniel, J.R.R. Interpreting strategic issues: Effects of strategy and the information-processing structure of top management teams. Acad. Manag. J. 1990, 33, 286-306.

75. Harms, P.D.; Wood, D.; Landay, K.; Lester, P.B.; Lester, G.V. Autocratic leaders and authoritarian followers revisited: A review and agenda for the future. Leadersh. Q. 2018, 29, 105-122. [CrossRef]

76. House, R.J. Path-goal theory of leadership: Lessons, legacy, and a reformulated theory. Leadersh. Q. 1996, 7, 323-352. [CrossRef]

77. Bass, B.M.; Bass, R. The Bass Handbook of Leadership: Theory, Research, and Managerial Applications; Simon and Schuster: New York, NY, USA, 2009.

78. De Hoogh, A.H.; Greer, L.L.; Den Hartog, D.N. Diabolical dictators or capable commanders? An investigation of the differential effects of autocratic leadership on team performance. Leadersh. Q. 2015, 26, 687-701. [CrossRef]

79. Vroom, V.H.; Yetton, P.W. Leadership and Decision-Making; University of Pittsburgh Press: Pittsburg, PA, USA, 1973; Volume 110.

80. De Luque, M.S.; Washburn, N.T.; Waldman, D.A.; House, R.J. Unrequited profit: How stakeholder and economic values relate to subordinates' perceptions of leadership and firm performance. Adm. Sci. Q. 2008, 53, 626-654. [CrossRef]

81. Goleman, D. Leadership that gets results. Harv. Bus. Rev. 2000, 78, 4-17.

82. Van Bunderen, L.; Greer, L.L.; Van Knippenberg, D. When interteam conflict spirals into intrateam power struggles: The pivotal role of team power structures. Acad. Manag. J. 2018, 61, 1100-1130. [CrossRef]

83. Greer, L.L.; Van Bunderen, L.; Yu, S. The dysfunctions of power in teams: A review and emergent conflict perspective. Res. Organ. Behav. 2017, 37, 103-124. [CrossRef]

84. Adams, J.S. Inequity in social exchange. In Advances in experimental social psychology; Elsevier: Amsterdam, The Netherlands, 1965; Volume 2, pp. 267-299.

85. Anderson, C.; Berdahl, J.L. The experience of power: Examining the effects of power on approach and inhibition tendencies. J. Personal. Soc. Psychol. 2002, 83, 1362. [CrossRef]

86. Tost, L.P.; Gino, F.; Larrick, R.P. When power makes others speechless: The negative impact of leader power on team performance. Acad. Manag. J. 2013, 56, 1465-1486. [CrossRef]

87. Davis, J.L.; Bell, R.G.; Payne, G.T.; Kreiser, P.M. Entrepreneurial orientation and firm performance: The moderating role of managerial power. Am. J. Bus. 2010, 25, 2. [CrossRef] 
88. Chua, J.H.; Chrisman, J.J.; Sharma, P. Defining the family business by behavior. Entrep. Theory Pract. 1999, 23, 19-39. [CrossRef]

89. Westhead, P.; Cowling, M. Family firm research: The need for a methodological rethink. Entrep. Theory Pract. 1998, 23, 31-56. [CrossRef]

90. Schepers, J.; Voordeckers, W.; Steijvers, T.; Laveren, E. The entrepreneurial orientation-performance relationship in private family firms: The moderating role of socioemotional wealth. Small Bus. Econ. 2014, 1-17. [CrossRef]

91. Bauweraerts, J.; Colot, O. Exploring nonlinear effects of family involvement in the board on entrepreneurial orientation. J. Bus. Res. 2017, 70, 185-192. [CrossRef]

92. Lambrecht, J.; Molly, V. Het Economische Belang van Familiebedrijven in België; FBNet Belgium: Kortrijk, Belgium, 2011.

93. Kammerlander, N.; Burger, D.; Fust, A.; Fueglistaller, U. Exploration and exploitation in established small and medium-sized enterprises: The effect of CEOs' regulatory focus. J. Bus. Ventur. 2015, 30, 582-602. [CrossRef]

94. Kollmann, T.; Stöckmann, C. Filling the entrepreneurial orientation-performance gap: The mediating effects of exploratory and exploitative innovations. Entrep. Theory Pract. 2014, 38, 1001-1026. [CrossRef]

95. Covin, J.G.; Slevin, D.P. Strategic management of small firms in hostile and benign environments. Strateg. Manag. J. 1989, 10, 75-87. [CrossRef]

96. Covin, J.G.; Lumpkin, G.T. Entrepreneurial orientation theory and research: Reflections on a needed construct. Entrep. Theory Pract. 2011, 35, 855-872. [CrossRef]

97. Covin, J.G.; Wales, W.J. The measurement of entrepreneurial orientation. Entrep. Theory Pract. 2011, 677-702. [CrossRef]

98. George, B.A. Entrepreneurial orientation: A theoretical and empirical examination of the consequences of differing construct representations. J. Manag. Stud. 2011, 48, 1291-1313. [CrossRef]

99. Hair, J.F.; Anderson, R.E.; Tatham, R.L.; Black, W.C. Multivariate Data Analysis; Prentice Hall: Upper Saddle River, NJ, USA, 1998.

100. Venkatraman, N.; Grant, J.H. Construct measurement in organizational strategy research: A critique and proposal. Acad. Manag. Rev. 1986, 11,71-87. [CrossRef]

101. Chrisman, J.J.; Patel, P.C. Variations in R\&D investments of family and nonfamily firms: Behavioral agency and myopic loss aversion perspectives. Acad. Manag. J. 2012, 55, 976-997.

102. Gregory, R.J. Psychological Testing: History, Principles, and Applications; Allyn \& Bacon: Boston, MA, USA, 2004.

103. Casillas, J.; Moreno, A. The relationship between entrepreneurial orientation and growth: The moderating role of family involvement. Entrep. Reg. Dev. 2010, 22, 265-291. [CrossRef]

104. McGee, J.E.; Peterson, M. The long-term impact of entrepreneurial self-efficacy and entrepreneurial orientation on venture performance. J. Small Bus. Manag. 2019, 57, 720-737. [CrossRef]

105. Kreiser, P.M.; Anderson, B.S.; Kuratko, D.F.; Marino, L.D. Entrepreneurial orientation and environmental hostility: A threat rigidity perspective. Entrep. Theory Pract. 2019. [CrossRef]

106. Cruz, C.; Nordqvist, M. Entrepreneurial orientation in family firms: A generational perspective. Small Bus. Econ. 2012, 38, 33-49. [CrossRef]

107. Evans, D.S.; Jovanovic, B. An estimated model of entrepreneurial choice under liquidity constraints. J. Political Econ. 1989, 97, 808-827. [CrossRef]

108. Holtz-Eakin, D.; Joulfaian, D.; Rosen, H.S. Entrepreneurial Decisions and Liquidity Constraints; 0898-2937; National Bureau of Economic Research: Cambridge, MA, USA, 1993.

109. Casillas, J.C.; Moreno, A.M.; Barbero, J.L. Entrepreneurial orientation of family firms: Family and environmental dimensions. J. Fam. Bus. Strategy 2011, 2, 90-100. [CrossRef]

110. Amason, A.C.; Sapienza, H.J. The effects of top management team size and interaction norms on cognitive and affective conflict. J. Manag. 1997, 23, 495. [CrossRef]

111. Van Doorn, S.; Jansen, J.J.; Van den Bosch, F.A.; Volberda, H.W. Entrepreneurial orientation and firm performance: Drawing attention to the senior team. J. Prod. Innov. Manag. 2013, 30, 821-836. [CrossRef]

112. Van Doorn, S.; Volberda, H.W. Entrepreneurial orientation and firm performance: The role of the senior team. Acad. Manag. Annu. Meet. Proc. 2009, 1-6. [CrossRef]

113. Sciascia, S.; Mazzola, P.; Chirico, F. Generational involvement in the top management team of family firms: Exploring nonlinear effects on entrepreneurial orientation. Entrep. Theory Pract. 2013, 37, 69-85. [CrossRef] 
114. Podsakoff, P.M.; MacKenzie, S.B.; Jeong-Yeon, L.; Podsakoff, N.P. Common method biases in behavioral research: A critical review of the literature and recommended remedies. J. Appl. Psychol. 2003, 88, 879-903. [CrossRef] [PubMed]

115. Harman, H. Modern Factor Analysis; University of Chicago Press: Chicago, IL, USA, 1967.

116. Podsakoff, P.M.; MacKenzie, S.B.; Podsakoff, N.P. Sources of method bias in social science research and recommendations on how to control it. Annu. Rev. Psychol. 2012, 63, 539-569. [CrossRef] [PubMed]

117. Lindell, M.K.; Whitney, D.J. Accounting for common method variance in cross-sectional research designs. J. Appl. Psychol. 2001, 86, 114. [CrossRef] [PubMed]

118. Pierce, J.L.; Kostova, T.; Dirks, K.T. Toward a theory of psychological ownership in organizations. Acad. Manag. Rev. 2001, 26, 298-310. [CrossRef]

119. Van Dyne, L.; Pierce, J.L. Psychological ownership and feelings of possession: Three field studies predicting employee attitudes and organizational citizenship behavior. J. Organ. Behav. Int. J. Ind. Occup. Organ. Psychol. Behav. 2004, 25, 439-459. [CrossRef]

120. MacKenzie, S.B.; Podsakoff, P.M. Common method bias in marketing: Causes, mechanisms, and procedural remedies. J. Retail. 2012, 88, 542-555. [CrossRef]

121. Hayes, A.F.; Montoya, A.K.; Rockwood, N.J. The analysis of mechanisms and their contingencies: PROCESS versus structural equation modeling. Australas. Mark. J. 2017, 25, 76-81. [CrossRef]

122. Liao, W.-L.; Fang, C.-Y. Applying an extended theory of planned behavior for sustaining a landscape restaurant. Sustainability 2019, 11, 5100. [CrossRef]

123. Hu, L.-T.; Bentler, P.M. Evaluating Model Fit. In Structural Equation Modeling: Concepts, Issues, and Applications; Sage Publications: Thousand Oaks, CA, USA, 1995.

124. Hoyle, R.H. Handbook of Structural Equation Modeling; Guilford Press: New York, NY, USA, 2012.

125. Aiken, L.S.; West, S.G.; Reno, R.R. Multiple Regression: Testing and Interpreting Interactions; Sage: Thousand Oaks, CA, USA, 1991.

126. Netter, J.; Wasserman, W.; Kutner, M. Applied Linear Statistical Models; Irwin Series Operations and Decision Sciences; McGraw Hill: Boston, MA, USA, 1990.

127. Kam, C.D.; Franzese, R.J. Modeling and Interpreting Interactive Hypotheses in Regression Analysis; The University of Michigan Press: Ann Arbor, MI, USA, 2007.

128. Finkelstein, S. Power in top management teams: Dimensions, measurement, and validation. Acad. Manag. J. 1992, 35, 505-538.

129. Kreiser, P.M.; Marino, L.D.; Weaver, K.M. Assessing the psychometric properties of the entrepreneurial orientation scale: A multi-country analysis. Entrep. Theory Pract. 2002, 26, 71. [CrossRef]

130. Lumpkin, G.T.; Dess, G.G. Clarifying the entrepreneurial orientation construct and linking it to performance. Acad. Manag. Rev. 1996, 21, 135-172. [CrossRef]

131. Amason, A.C. Distinguishing the effects of functional and dysfunctional conflict on strategic decision making: Resolving a paradox for top management teams. Acad. Manag. J. 1996, 39, 123-148.

132. Bluedorn, A.C.; Martin, G. The time frames of entrepreneurs. J. Bus. Ventur. 2008, 23, 1-20. [CrossRef]

133. Crossan, M.; Cunha, M.P.E.; Vera, D.; Cunha, J. Time and organizational improvisation. Acad. Manag. Rev. 2005, 30, 129-145. [CrossRef]

134. Shi, W.; Sun, J.; Prescott, J.E. A temporal perspective of merger and acquisition and strategic alliance initiatives: Review and future direction. J. Manag. 2012, 38, 164-209. [CrossRef]

135. Nadkarni, S.; Chen, J. Bridging yesterday, today, and tomorrow: CEO temporal focus, environmental dynamism, and rate of new product introduction. Acad. Manag. J. 2014, 57, 1810-1833. [CrossRef]

136. Souitaris, V.; Maestro, B.M. Polychronicity in top management teams: The impact on strategic decision processes and performance of new technology ventures. Strateg. Manag. J. 2010, 31, 652-678. [CrossRef]

137. Lyon, D.W.; Lumpkin, G.T.; Dess, G.G. Enhancing entrepreneurial orientation research: Operationalizing and measuring a key strategic decision making process. J. Manag. 2000, 26, 1055-1085. [CrossRef]

138. Miles, R.E.; Snow, C.C.; Meyer, A.D.; Coleman, H.J., Jr. Organizational strategy, structure, and process. Acad. Manag. Rev. 1978, 3, 546-562. [CrossRef]

139. Laverty, K.J. Economic "short-termism": The debate, the unresolved issues, and the implications for management practice and research. Acad. Manag. Rev. 1996, 21, 825-860.

140. Ward, J.L. Growing the family fusiness: Special challenges and best practices. Fam. Bus. Rev. 1997, 10, 323-337. [CrossRef] 
141. Sharma, P.; Nordqvist, M. A typology for capturing the heterogeneity of family firms. Acad. Manag. Annu. Meet. Proc. 2007, 1-6. [CrossRef]

142. Klein, S.B.; Astrachan, J.H.; Smyrnios, K.X. The F-PEC scale of family influence: Construction, validation, and further implication for theory. Entrep. Theory Pract. 2005, 29, 321-339. [CrossRef]

143. Kellermanns, F.W.; Eddleston, K.A.; Barnett, T.; Pearson, A. An exploratory study of family member characteristics and involvement: Effects on entrepreneurial behavior in the family firm. Fam. Bus. Rev. 2008, 21, 1-14. [CrossRef]

144. Chandler, J.A.; Zachary, M.A.; Brigham, K.H.; Payne, G.T. Long-term orientation: Reviewing the past and identifying future opportunities for family business research. In The Routledge Companion to Family Business; Routledge: London, UK, 2016; pp. 100-119.

145. Hernández-Perlines, F.; Rung-Hoch, N. Sustainable entrepreneurial orientation in family firms. Sustainability 2017, 9, 1212. [CrossRef]

146. Li, F.; Li, T.; Minor, D. CEO power, corporate social responsibility, and firm value: A test of agency theory. Int. J. Manag. Financ. 2016, 12, 15. [CrossRef]

147. Pan, X.; Sha, J.; Zhang, H.; Ke, W. Relationship between corporate social responsibility and financial performance in the mineral Industry: Evidence from Chinese mineral firms. Sustainability 2014, 6, 4077-4101. [CrossRef]

148. Zellweger, T.; Nason, R.S. A stakeholder perspective on family firm performance. Fam. Bus. Rev. 2008, 21, 203-216. [CrossRef]

149. Hernández-Linares, R.; Kellermanns, F.W.; López-Fernández, M.C.; Sarkar, S. The effect of socioemotional wealth on the relationship between entrepreneurial orientation and family business performance. Brq Bus. Res. Q. 2019. [CrossRef]

150. Nonaka, I. A dynamic theory of organizational knowledge creation. Organ. Sci. 1994, 5, 14-37. [CrossRef]

151. Chirico, F.; Salvato, C. Knowledge integration and dynamic organizational adaptation in family firms. Fam. Bus. Rev. 2008, 21, 169-181. [CrossRef] 